
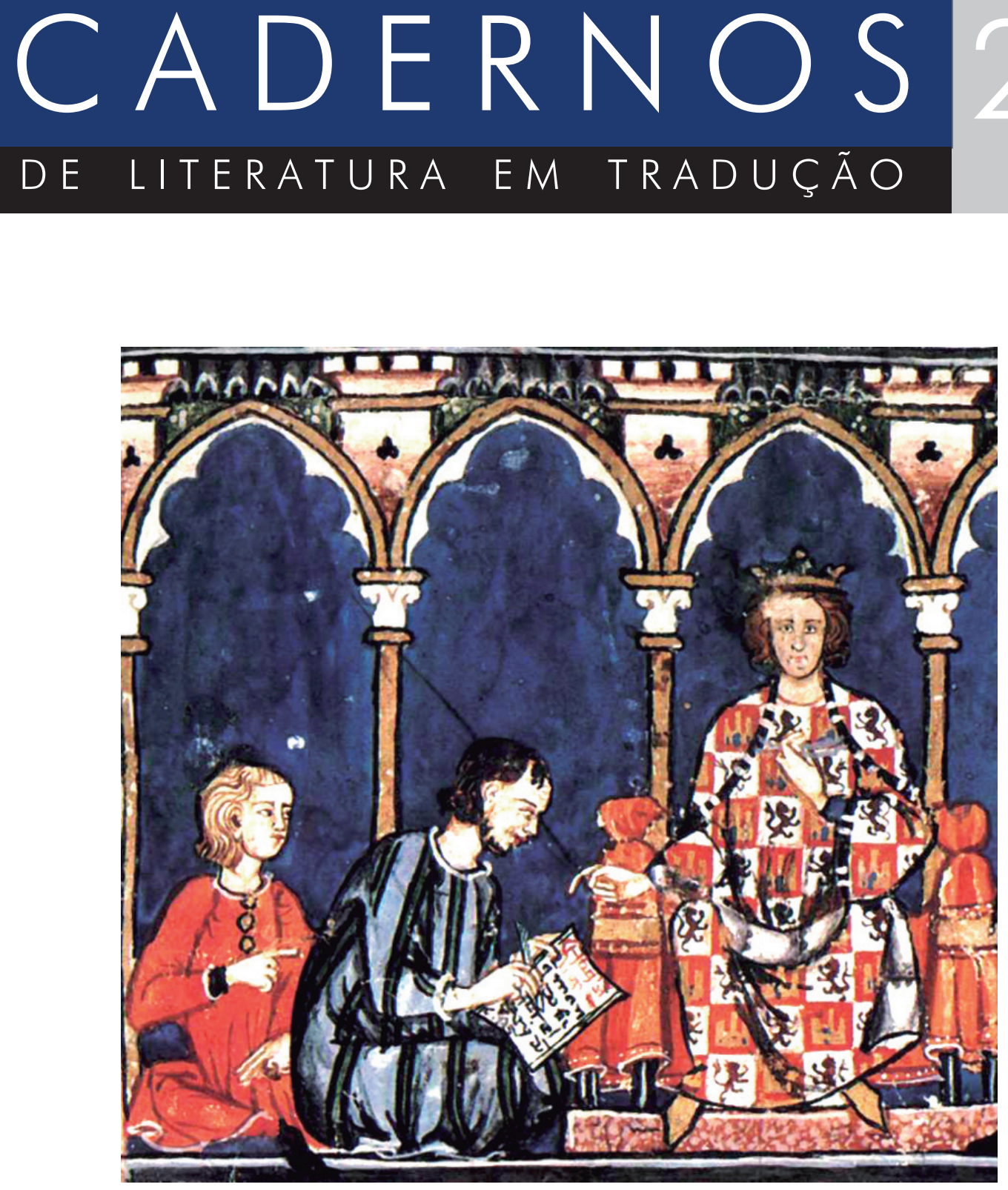

Tradutores da chamada Escola de Toledo com Afonso $X$ de Castela 


\title{
A morte de um Poeta. Tradução poética para o português da estreia literária de Mikhail Iúrevitch Lérmontov (1814-1841)
}

Pedro Augusto Pinto ${ }^{1}$

\begin{abstract}
Resumo: O presente artigo busca introduzir e comentar a tradução inédita que aqui apresentamos do poema "A morte de um poeta", de Mikhail Lérmontov, um dos mais importantes autores russos do século XIX. Para além de algumas escolhas feitas ao longo do processo tradutório, tentaremos apresentar os pressupostos teóricos de que nos valemos, assim como um breve panorama do contexto histórico e cultural em que se inserem a obra de Lérmontov como um todo, e sobretudo o poema em questão.
\end{abstract}

Palavras-chave: Romantismo; Lírica; Tradução; Literatura Russa.

\section{Introdução: Lérmontov, um poeta de seu tempo}

Apesar de praticamente ignorado no Brasil, Mikhail Iúrevitch Lérmontov (1814-1841) é considerado na Rússia e no mundo como um dos principais nomes da literatura russa do século XIX, tendo, por um lado, inaugurado o romance psicológico na prosa do país eslavo (com sua obra "O herói de nosso tempo") ${ }^{2}$ e, por outro, encerrado virtualmente a "Era de Ouro" da poesia russa, dando lugar ao predomínio da prosa que marcaria a cena literária do país até o ad-

1 Doutorando em Letras Estrangeiras e Tradução, Mestre em Literatura e Cultura Russa e Bacharel Licenciado em História pela Faculdade de Filosofia, Letras e Ciências Humanas da Universidade de São Paulo (FFLCH - USP) - pedro.augusto.pinto@usp.br

2 A obra possui em português uma tradução já um tanto antiga, feita por Paulo Bezerra (Lérmontov, 1999). 
vento do Simbolismo, no final do século XIX. Tal transição não foi apenas simbólica, na forma de sua morte precoce em um duelo: segundo Eikhenbaum (1924, 1987), Lérmontov já compunha sua poesia em um período de crise das formas poéticas e de uma profunda transformação no mercado e no público literário russos, o que levou o poeta a buscar em seus versos uma intensidade emocional crescente, e a absorver neles o registro prosaico e retórico que viria posteriormente a marcar, sobretudo, a poesia militante de Nikolai Nekrássov (1821-1877) - grande expressão poética de uma época onde, diante de nomes como o de Tolstói e Dostoiévski e diante da urgência do debate social e político, a poesia já não tinha mais lugar.

O poema que aqui apresentamos, embora não tenha sido o primeiro de sua autoria a ser publicado, marcou todavia a entrada triunfal de Lérmontov na cena literária russa, ao reverberar a indignação quase geral em meio à aristocracia reformista diante da morte do poeta Aleksandr Púchkin em um duelo em 1837. O poema circulou em cópias manuscritas até chegar nas mãos do próprio tsar Nicolau I, o que rendeu a Lérmontov, pelo tom furibundo da obra (sobretudo da conclusão do poema, conforme se verá), o primeiro de seus muitos exílios no Cáucaso. A extrema afinação entre os versos e o espírito de seu público serviu para tornar o nome de Lérmontov rapidamente conhecido, ao mesmo tempo que, pela maestria poética com que cantou a morte de Púchkin, o poeta de então 23 anos passou a ser visto como o herdeiro legítimo do gênio que acabara de partir. Ademais, para além de sua enorme significação histórica, "A morte de um poeta" é um exemplo significativo de alguns recursos que caracterizaram obra madura do autor: lá encontramos a multiplicidade de metros, a combinação de recursos oriundos tanto da ode quanto da elegia, uma grande força oratória e um tom profundamente sentimental - elementos que corroboram a identificação do poeta com o Romantismo, marca da literatura europeia da época e da poesia de Lérmontov em particular.

\section{Recriando uma poética romântica}

Pode-se dizer que Lérmontov é, no sistema literário russo, o maior poeta de expressão romântica - compreendendo-se o adjetivo não tanto em termos de escola literária, com o que sua obra despontaria como um índice de transição para o Realismo, quanto como um fenômeno histórico-cultural, intimamente associado às transformações políticas, econômicas e mentais experienciadas pelas sociedades europeias na primeira metade do século XIX (SALIBA 2003, pp. 14-15; LÖWY; 
SAYRE 1995, pp. 34-38). Tal correspondência é sugerida pelo fato de, em sua obra, poder-se observar toda uma série de preferências temáticas (apelo ao exótico, à natureza, ao nacional e à Idade Média; individualismo quase anárquico, oposto aos padrões artificiais de sociabilidade; etc.) identificadas por Saliba (2003, p. 26) como sintomas da "síndrome de nenhum-lugar", fenômeno que caracterizou boa parte da intelectualidade europeia entre 1789 e 1848.

Este quadro se confunde com certa postura filosófica que poderíamos chamar de melancólica (também conhecida na época sob o nome de spleen ou mal $d u$ siècle), presente tanto nos textos quanto na curta vida do poeta, e que implicou em sua criação uma constante desilusão, uma ironia recorrente e um anseio incurável pela eternização de si mesmo e do mundo (cf. LAMBOTTE 2000; STAROBINSKI 2012). É nesse sentido que a obra de Lérmontov apresenta uma profunda correlação com seu contexto histórico: a consciência nostálgica da perda do passado, conjugada com o desprezo pelo presente e o receio do futuro - traços recorrentes na criação do poeta -, se associa fundamentalmente à inauguração, após a Revolução Francesa, de um novo tempo histórico, apreendido pela intelectualidade europeia como incerto e trágico (KOSELLECK 2006, p. 37). No contexto especificamente russo, tais transformações se associam ao ambiente reacionário e repressor que se abateu progressivamente sobre a intelligentsia e a sociedade do país após o Congresso de Viena (1815), e sobretudo após a supressão da Insurreição Dezembrista (1825). ${ }^{3}$

Em consonância com o que havia de mais atual na literatura de seu tempo, Lérmontov operou uma curiosa conjunção de influências tanto da literatura da Europa Ocidental, sobretudo de Byron, mas também de Chateaubriand, Lamartine, Musset, Vigny, Heine e Goethe, quanto da poesia russa de seu tempo, como a de Púchkin, Bátiuchkov, Jukóvski e Karamzin - referências de que o poeta se valia fartamente em empréstimos diretos e reelaborações estruturais sui generis, de modo a dar à sua poesia a densidade sentimental que o público russo começava a exigir na década de 1830 (EIKHENBAUM 1924; SIÉRMAN 2003). Conforme fica claro no poema que vamos apresentar, a variedade e a liberdade significativamente

3 A Insurreição Dezembrista, assim chamada por ter ocorrido em 14 de dezembro de 1824 (26 de dezembro no calendário gregoriano), foi uma revolta de setores reformistas do oficialato russo rebelada no dia da coroação do futuro tsar Nicolau I. A pauta da revolta era vaga, e ia da exigência de um governo constitucional à coroação do arquiduque Constantino e à abolição da servidão. Sem qualquer apoio amplo da sociedade, e sobretudo do campesinato analfabeto, o motim foi rapidamente desbaratado, e foi o marco de uma era de profunda repressão e reacionarismo políticos, sendo os envolvidos mandados para o Cáucaso e para a Sibéria. 
maiores (em relação à poesia então consagrada) no uso de metros e construções estróficas também seriam marcas do poeta no desenvolvimento da poesia russa (MANÚILOV 1981, p. 542), em uma época que se destacava pelo esgotamento expressivo dos gêneros que predominaram até então (sobretudo a ode e a elegia). Neste processo, Lérmontov colaborou decompondo e recompondo os metros e temas já estabelecidos, utilizando-os em formas mistas e idiossincráticas conforme as necessidades expressivas suas e de seu tempo.

São fatores como estes que fazem do poeta uma peça chave na história da literatura russa, de maneira simultaneamente retrospectiva e prospectiva: por um lado, coube a ele encerrar a tarefa empreendida por Púchkin e sua geração de nacionalizar o repertório estrangeiro que vinha sendo importado ao longo do século XVIII, abandonando de uma vez as referências à Antiguidade e simplificando o léxico empregado (MANÚILOV 1981, p. 541); ao mesmo tempo, Lérmontov lançou as bases para diversas práticas poéticas futuras, e até contraditórias entre si, como os temas cívicos, ao gosto dos eslavófilos e dos radicais fruto da apropriação pessoal de Lérmontov da tradição grandiloquente das odes -, e filosófico-individuais, aproveitados por nomes como Afanássi Fet e Fiódor Tiútchev - resultado da reformulação singular da elegia empreendida pelo jovem poeta. Algumas formas específicas usadas por Lérmontov, como os poemas em três estrofes ou a expansão dos metros iâmbicos, consagrados por Púchkin em disposições quaternárias, também viriam a se tornar futuramente canônicos. Através da ressignificação do seu universo simbólico, sobretudo aquele dado ao demonismo e ao exotismo, Lérmontov exerceria também grande influência sobre Aleksandr Blok e sobre o Simbolismo russo de maneira geral, enquanto, num outro plano, seus versos cívicos e seu individualismo hiperbólico seriam determinantes para a obra de Vladímir Maiakóvski (MANÚILOV 1981, pp. 63, 276).

Não obstante, tendo tais considerações fundamental importância crítica para a apreensão do universo simbólico e do contexto do poeta, e tendo servido de baliza para a tradução que apresentaremos, sua transição para a prática tradutória não foi simples nem equacionável. Por um lado, ao elucidar as referências e significações do poema, destacando sua relevância e autenticidade, o aparato crítico surge como parâmetro a ser seguido, fiança hipotética da relação de reciprocidade almejada entre o texto russo e o português. Por outro lado, porém, até agora limitamo-nos a ideias, e a natureza mesma do material poético exige que se sacrifique a fidelidade a ideias em prol da fidelidade a signos: a tradução é um fenômeno histórico (CAMPOS 2006, pp. 35-36), e qualquer tentativa de transposição de uma língua para a outra será marcada pelo tempo em que a operação 
se desdobra, ${ }^{4}$ dando conta apenas daqueles aspectos do texto vertido que se comunicam ao contexto em que se traduz. Uma tradução que abarque absolutamente todos os elementos de uma determinada obra seria, ademais, impossível por definição, pois não implicaria tradução, mas identidade plena, e portanto tautologia. Somando-se a tais fatos a enorme quantidade de problemas, e sobretudo de binômios (sentido/forma, abrasileirar/estrangeirizar, linguagem antiga/atual, apelo a modelos consagrados da língua-alvo/recurso à inovação, etc.) que perpassam o ato tradutório, e a impossibilidade de sua determinação apriorística, optamos no presente trabalho por seguir, frente a tais questões, certas vertentes modernas e brasileiras diretamente ligadas à tradução de poesia russa para a língua portuguesa, e que viram na prática poética e no trabalho crítico as duas tarefas essenciais para se assimilar a estética do que se traduz.

Assim sendo, partiremos em primeiro lugar de uma compreensão da poesia como emprego expressivo do signo linguístico tido enquanto objeto ${ }^{5}$ - proposição que implica uma problematização específica da transposição de textos poéticos entre duas línguas, como conclui Roman Jakobson:

"Em poesia, as equações verbais são elevadas à categoria de princípio construtivo do texto. As categorias sintáticas e morfológicas, as raízes, os afixos, os fonemas e seus componentes (traços distintivos) - em suma, todos os constituintes do código verbal - são confrontados, justapostos, colocados em relação de contiguidade de acordo com o princípio de similaridade e de contraste, e transmitem assim uma significação própria. A semelhança fonológica é sentida como um parentesco semântico. O trocadilho, ou, para empregar um termo mais erudito e talvez mais preciso, a paranomásia, reina na arte poética; quer esta dominação seja absoluta ou limitada, a poesia, por definição, é intraduzível. Só é possível a transposição criativa [...]" (JAKOBSON 1969, p. 72).

4 A diacronia é parte inerente do ato tradutório, conforme explica F. Aubert: "entre a produção do ato comunicativo inicial e a do ato comunicativo tradutório que se propõe como seu equivalente ocorre necessariamente um certo intervalo. Tal intervalo pode ser extremamente breve (...). Pode, inversamente, estender-se sobre dias, semanas, anos ou, até, séculos e milênios. (...) Na tradução de textos cujos originais remontam a um ou mais séculos, manifestam-se diferenças diacrônicas marcantes, não apenas de natureza linguística como também de natureza referencial, de visão de mundo" (AUBERT 1994, pp. 15-16). Deste modo, a busca pela compreensão da "visão de mundo" do poema traduzido - neste caso, o Romantismo - não implicou nem tampouco pretendeu a anulação da diacronia.

5 Tal é, no fundo, o princípio subjacente às formulações de "informação estética" (CAMPOS 2006, pp. 32-33), "forma mais condensada de informação verbal" (POUND 1970, pp. 40-41), "palavra-coisa" (SARTRE, apud CAMPOS 2006, p. 34). 
Embora a impossibilidade da tradução de poesia já tenha sido constatada inúmeras vezes e por diversos autores, a análise de Jakobson se destaca por concluir precisamente desta impossibilidade a possibilidade real de se verter textos poéticos de uma língua para outra, através da "transposição criativa". O formalista, porém, não entra em maiores detalhes sobre como ela poderia ou deveria se dar, de modo que tal tarefa acabou sendo assumida pelo concretista Haroldo de Campos. Para ele, a tradução de "textos criativos" - ou seja, para além da poesia, também a de prosa experimental ou de invenção

será sempre recriação, ou criação paralela, autônoma, porém recíproca. Quanto mais inçado de dificuldades esse texto, mais recriável, mais sedutor enquanto possibilidade aberta de recriação. Numa tradução dessa natureza, não se traduz apenas o significado, traduz-se o próprio signo, ou seja, sua fisicalidade, sua materialidade mesma [...] (CAMPOS 2006, p. 35).

Campos enfatiza, nesse sentido, o princípio do isomorfismo que norteia a tarefa recriadora: embora original e tradução constituam informações estéticas distintas e autônomas, ainda assim devem estar ligadas pela constituição análoga de suas formas, cristalizando-se dentro de um mesmo sistema (CAMPOS 2006, p. 34). ${ }^{6}$

Sob a clara influência de Ezra Pound, Campos ainda parece indicar o sentido essencialmente crítico da tarefa recriadora: primeiramente, este se observa na escolha mesma do autor e da obra a serem traduzidos, o que implica seu resgate e atualização; depois, é visto na "vivência interior do mundo e da técnica do traduzido” (CAMPOS 2006, p. 43), ou seja, na compreensão formal e histórica do objeto, de modo a decodificá-lo visando à sua recodificação em outra língua e em outro tempo. Nesse sentido, mais do que ao sentido literal ou semântico das palavras, ou à forma a ele falsamente oposta, cumpre ao tradutor a fidelidade ao tom do traduzido, entendido como dicção característica da obra, e como seu verdadeiro cerne quando se trata de recriá-la.

A posição sintetizada em Haroldo de Campos tem como consequência necessária uma maior relevância das escolhas feitas pelo tradutor, não mais entendido como simples técnico, mas como crítico. Assim, assumem particular importância

6 José Paulo Paes, porém, crê que "visa-se [...] menos a uma impossível isomorfia - perfeita simetria no espírito e na letra - do que a uma possível paramorfia - a similitude de forma e de significado que as idiossincrasias dos dois idiomas franqueados pela ponte tradutória permita." Entendemos que Haroldo de Campos não tinha em vista uma "perfeita simetria", de modo que mantivemos o seu conceito incorporando a maior precisão que José Paulo Paes julga necessário lhe dar (PAES 1990, p. 70). 
para o trabalho tradutório os relatos de tradutores ligados pessoal ou intelectualmente a essa visão acerca da tradução, tais como os de Boris Schnaiderman (2011), Paulo Rónai (1956, 1981) e José Paulo Paes (1990). Menos preocupados em dar roupagem teórica às suas formulações, sua própria experiência profissional de tradutores literários levou-os a ideias similares às de Haroldo de Campos a partir de situações concretas e específicas - fato tanto mais notável quanto o primeiro deles se consagrou, justamente, pela tradução e pelo estudo de autores russos.

Foi, portanto, no sentido de um enfoque crítico particular, enquanto opção específica e elemento norteador da tarefa tradutória, que propusemos o uso do conceito de Romantismo para a tradução da obra de Lérmontov, conforme ficará mais claro no decorrer da leitura. O resultado poderá ser avaliado a seguir em um exemplo concreto, ao que se seguirá uma avaliação mais pormenorizada das questões envolvidas especificamente na tradução de "A morte de um poeta". 


\section{Tradução (LÉRMONTOV, 1964 v. 1: 21-23)}

Смерть поэта

Погиб поэт! - невольник чести -

Пал, оклеветанный молвой,

С свинцом в груди и жаждой мести,

Поникнув гордой головой!..

Не вынесла душа поэта

Позора мелочных обил,

Восстал он против мнений света

ОАин, как прежАе... и убит!

Убит!.. к чему теперь рыданья,

Пустых похвац ненужный хор

И жалкий мепет оправАанья?

Судьбы свершился приговор!

Не вы Аь сперва так злобно гнали

Его свободный, смелый Аар

И Аля потехи раздували

Чуть затаившийся пожар?

Что ж? веселитесь... - он мучений

Последних вынести не мог:

Угас, как светоч, Аивный гений,

Увяц торжественный венок.

Его убийца хлаАнокровно

Навел удар... спасенья нет:

Пустое сердце бьется ровно.

В руке не Арогнул пистолет,

И что за Аиво?.. издалека,

Подобный сотням беглецов,

На АовАю счастья и чинов

Заброшен к нам по воле рока;

Смеясь, он дерзко презирал

Земли чужой язык и нравы;

Не мог щадить он нашей славы;
A morte de um poeta

Prisoneiro da honra, difamado,

Curvando sua fronte altiva, ereta,

De chumbo e ódio o peito perfurado,

Sedento por vingança, morre um Poeta!

5 Não pôde suportar, sua alma humana,

A ofensa vergonhosa, infame e vil,

Ergueu-se contra a opinião mundana,

Só, como sempre e... morto a sangue frio!

Morto!... Agora, para quê lamentos,

10 Os coros de elogios sem sentido,

$\mathrm{O}$ balbucio de torpes argumentos?

O decreto da sina foi cumprido!

Não fostes quem primeiro perseguistes,

Maldosos, o seu dom livre e ousado

15 E pelo simples tédio produzistes

Um incêndio de um tição quase apagado?

E então? Ficai contentes... tais torturas

Enfim ele não pôde suportar:

Tomba o gênio - um cometa! - das alturas,

20 E estão murchas as flores sobre o altar.

O cínico assassino, sem clemência

Deu-lhe o golpe... não houve salvação:

No peito, vazio, a mesma cadência -

Nem tremia a pistola em sua mão.

25 E qual é a surpresa? Se a vagar Igual a outros cem mil fugitivos, Em busca de alegria e distintivos

$\mathrm{O}$ destino o atirou em nosso lar?

A rir-se, o descarado desprezava

30 Os costumes alheios, e sua voz;

Não poupou-nos a glória: fez-se algoz, 
Не мог понять в сей миг кровавый,

На что́ он руку поднимал!..

И он убит - и взят могилой,

Как тот певец, неведомый, но милый,

Аобыча ревности глухой,

Воспетый им с такою чудной силой,

Сраженный, как и он, безжалостной рукой.

Зачем от мирных нег и Аружбы простодушной

Вступим он в этот свет, завистАивый и Аушный

А^я сердца вольного и пламенных страстей?

Зачем он руку дац клеветникам ничтожным,

Зачем повериц он словам и маскам Аожным,

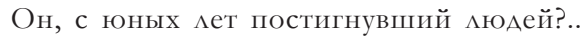

И прежний сняв венок,- они венец терновый,

Увитый Ааврами, надеми на него:

Но иглы тайные сурово

Язвили славное чело;

Отравлены его последние мгновенья

Коварным шепотом насмешливых невежА, И умер он - с напрасной жаждой мщенья,

С досадой тайною обманутых надежА.

Замолкли звуки чудных песен,

Не раздаваться им опять:

Приют певца угрюм и тесен,

И на устах его печать.
Não pôde compreender, num instante atroz, Contra o quê sua mão se levantava!

E está morto - levou-o a sepultura

35 Qual o cantor obscuro, mas cheio de doçura - A presa de um ser cego e invejoso -, Celebrado por ele em divinas alturas, E qual ele, ferido por um braço assim impiedoso.

Por que é que foi deixar a meiga, simples amizade,

40 A ternura tranquila, em prol da odiosa sociedade,

Que sufoca o peito livre e as mais ardentes paixões?

Por que foi dar a mão a bisbilhoteiros mesquinhos,

Por que acreditou em falsas frases e carinhos, Bem ele, desde cedo compreensor das multidões!...

45 Finda a coroa de outrora, eles enfim lhe puseram

Entre louros, a coroa de espinhos, enganosa:

Mas feridas ocultas, sem espera,

Abriram-se em sua fronte gloriosa;

Seus últimos minutos foram assim envenenados

50 Com o cretino cochicho de trocistas imbecis, E, sedento por vingança, morreu, frustrado, Com um oculto desgosto, com esperanças pueris.

Das divinas canções, findou-se o ardor:

Não hão mais de espalhar-se novamente.

55 É estreito e escuro o abrigo do cantor, E os seus lábios, selados, 'stão silentes. 
Pedro Augusto Pinto. A morte de um Poeta. Tradução poética para o português da estreia...

А вы, налменные потомки

Известной подлостью прославленных отцов,

Пятою рабскою поправшие обломки

Игрою счастия обиженных родов!

Вы, жаАною толпой стоящие у трона,

Свободы, Гения и САавы палачи!

Таитесь вы под сению закона,

Пред вами суд и правда - всё молчи!..

Но есть и божий суА, наперсники разврата!

Есть грозный суА: он жАет;

Он не доступен звону змата,

И мысли и дела он знает наперед.

Тогда напрасно вы прибегнете к зцословью:

Оно вам не поможет вновь,

И вы не смоете всей вашей черной кровью

Поэта праведную кровь!
Quanto a vós, superbíssimos herdeiros,

Cujos pais só a infâmia poderia consagrar,

Cujos pés de capacho pisam os restos derradeiros

60 De linhagens melindradas pelas voltas do azar!

Ó vós, turba sedenta, que estais sempre junto ao rei,

Carrascos da Grandeza, do Gênio, da Liberdade!

Escondei-vos à sombra arbitrária da lei!

Ante a vós, tudo cala: o juízo, a verdade...!

65 Mas há um juízo divino, ó servos da indecência!

Um juízo final, à espera;

Alheio ao som do ouro, e com ciência

De cada pensamento e cada ação de cada era.

E em vão direis calúnias nestes últimos segundos:

70 Nem elas estarão do vosso lado,

Nem podereis lavar com todo o vosso sangue imundo

O sangue de um Poeta injustiçado!

\section{Comentário}

O poema que aqui apresentamos em tradução é um dos de maior relevância para obra de Lérmontov, e talvez para a história da poesia russa. Tal relevância é, certamente, em parte extraliterária - não se pode ter uma dimensão precisa de sua força nem de seu universo referencial sem se ter em mente, em primeiro lugar, "o poeta" a quem se faz menção, Alexandr Serguéevitch Púchkin, morto em um duelo em 1837, quando já era considerado um dos maiores nomes da literatura russa de seu tempo. O poema de Lérmontov insere-se, assim, em um rol de produções poéticas elaboradas à época como reação à morte do autor de Evguéni Oniéguin, sendo provavelmente, dentre elas, a mais contundente - não por acaso, a circulação do poema de Lérmontov em forma manuscrita lhe rendeu das mãos do imperador Nicolau I, sobretudo pela parte final (versos 58-73) posteriormente 
adicionada ao texto, o seu primeiro exílio no Cáucaso. É importante observar que a versão original do poema terminava no verso 57 , e contava com a seguinte epígrafe - em iambos brancos polimétricos, que vertemos em metros distintos e igualmente desprovidos de rimas -, endereçada ao próprio tsar Nicolau I:

Vingança! Vingança, Majestade!

Desabo junto aos teus pés:

Sê direito, e castiga o assassino,

De modo que sua pena, assim, aclame,

Nas eras que virão, tua justiça,

E nele tenham exemplo os malfeitores.
Отмщенья, государь, отмщенья!

ПаАу к ногам твоим:

Будь справедлив и накажи убийцу,

Чтоб казнь его в позАнейшие века

Твой правый суА потомству возвестила,

Чтоб видели зАодеи в ней пример.

Por não acompanhar a edição utilizada, e por ter sido praticamente substituída pelos versos 58-73, preferiu-se não reproduzi-la no corpo do poema. Embora não tenha nenhum traço estético particularmente notável, esta epígrafe apresenta grande valor histórico para o desenvolvimento intelectual de Lérmontov. De acordo com Siérman (2003), ela expõe a visão política e histórica do poeta até o momento de seu primeiro exílio: a crença em uma comunhão entre o tsar e o povo, frustrada apenas pela nobreza palaciana. Uma crença que os eventos sucedidos após a circulação do poema em forma manuscrita haveriam fatalmente de dissipar:

\begin{abstract}
"'A morte de um poeta', escrita sob a influência de um poderoso sentimento de indignação e sem a ponderação de possíveis consequências, foi para Lérmontov e para seus amigos um teste singular de sua concepção acerca de um consenso nacional, da possibilidade de uma união entre o tsar e a nação contra a aristocracia palaciana. A reação do tsar a 'A morte de um poeta', convém dizer, e à própria morte de Púchkin, foi unívoca. O tsar deixou claro - com suas ações - que se apoiava nesta aristocracia palaciana, que via nela uma aliada, e que não toleraria nenhuma invectiva contra ela" (SIÉRMAN 2003, pp. 118-119, tradução nossa). ${ }^{7}$
\end{abstract}

7 “Сметь поэта", написанная под влиянием могучего чувства негодования и без взвешивания возможных последствий, была Аля Аермонтова и его друзьей своеобразной проверкой их концепции национального консенсуса, возможности союза царя и нации против придворной аристократии. Реакция царя на 'Смерть поэта', как кстати сказать, и на самую смерть Пушкина, была однозначной. Царь заявил - своими действиями -, что он на эту придворную аристократию опирается, видит в ней своего союзника и не потерпит никаких выступлений против нее. 
A epígrafe teria dado lugar à conclusão (versos 57 a 73), assim, no momento em que ficou claro para Lérmontov que o tsar não apenas não puniria George d'Anthès, responsável pela morte de Púchkin, como era mais simpático a ele do que ao poeta assassinado, cujas inclinações políticas liberais não eram segredo para ninguém.

Não é difícil, portanto, julgar a crise ideológica e até mesmo ética que deve ter se abatido sobre Lérmontov ao ter seu clamor recusado, e ser posteriormente punido por sua ingênua confiança na coroa. A história do poema, entre a epígrafe inicial e a conclusão posterior, nos revela que, desamparado pela justiça terrena com a qual contava, o poeta, na figura do eu lírico, passa a voltar seus clamores para a justiça divina.

Em linhas gerais, foram tais razões de natureza extralitéraria que propiciaram a verdadeira estreia do poeta nas letras russas, em 1837, e que fazem com que este poema apareça em primeiro lugar no volume de poemas de suas obras completas (o que também pode ser explicado por razões políticas, sendo do interesse do regime soviético pintar todo e qualquer autor clássico como um revolucionário em seu próprio tempo). No contexto de uma publicação impressa, tais informações teriam fatalmente de ser transmitidas por meio de uma introdução ou uma nota de fim, uma vez que o recurso a uma nota de rodapé, em meio ao poema, constituiria um ruído na informação estética, não tendo relação direta com a sua forma.

Ainda assim é digno de nota que o nome de Púchkin não surja em nenhum momento do texto - seja porque isso estivesse suficientemente claro para os leitores contemporâneos, seja porque Lérmontov quisesse dar um alcance maior e mais autônomo à sua obra. Do mesmo modo, a despeito da importância fundamental do episódio para a compreensão da obra, tampouco as condições da morte de Púchkin (descritas no poema de um modo certamente dramático, mas pouco detalhado), ou ainda quem seriam os "superbíssimos herdeiros" do verso 58 (que, sabemos, é uma referência direta ao poema de Púchkin "Minha genealogia", onde se ridiculariza a nobreza ascendida no século XVIII unicamente em virtude da bajulação) são dados na obra de Lérmontov. É nesse sentido que, juntando-se ainda a força retórica, o sentimentalismo abundante na adjetivação e nas comparações, a riqueza métrica e melódica e a dramaticidade do assassinato de um gênio romântico, o poema pôde constituir não apenas um panfleto de ocasião, mas também uma obra verdadeiramente autônoma, ainda que a fortuna crítica, como sucede com qualquer obra, possa sempre vir a enriquecê-la. Nas palavras de Eikhenbaum: 
O poema escrito por ocasião da morte de Púchkin (em 1837) surge-nos como um brilhante modelo do estilo oratório e do verso declamatório de Lérmontov. À nossa frente está o discurso apaixonado de um orador: os períodos discursivos, sucedendo-se uns aos outros, formam toda uma escala de timbres vocais - do lastimoso ao enfurecido, repleto de ameaças, e nos intervalos entre estes períodos surgem repetições patéticas, exclamações e interrogações, atrás das quais se sente a gesticulação emocional (EIKHENBAUM 1924, p. 107, tradução nossa). ${ }^{8}$

Foi por conta de tal autonomia constitutiva que optamos pelo artigo indefinido no título - algo que o russo, na ambiguidade que a inexistência do artigo na língua sempre implica para as traduções, deixa em aberto. A versão "A morte do Poeta", embora mais lógica, deixaria o poema demasiadamente atrelado à morte de A. S. Púchkin, enquanto o artigo indefinido, sem perder a sua referência concreta, traz ao poema dimensões cósmicas, em nada estranhas ao espírito do Romantismo, de um conflito entre o gênio injustiçado - qualquer que ele seja - e a sociedade que o circunda. Tal opção é ainda referendada pelo fato já observado de o nome de Púchkin não figurar uma única vez no poema inteiro, ainda que se faça menção direta a pelo menos três obras - o "Evguéni Oniéguin" nos versos 36-39, o "André Chénier", nos versos 40-43, e Moiá Rodoslovnaia ("Minha genealogia"), nas linhas 58-61. A referência ao "Evguéni Oniéguin" se dá pela comparação entre o destino de Lénski, morto num duelo por Oniéguin, e o do próprio Púchkin, enquanto a menção ao "André Chénier" aparece na interrogação acerca das escolhas do poeta ao se afastar de um ambiente pintado como idílico. Já o poema "Minha genealogia" surge através do vocabulário empregado na acusação que encerra o poema, sobretudo no termo oblómok (resto, pedaço) se referindo à linhagem da nobreza palaciana. Não tendo esse poema sido traduzido para o português, não nos preocupamos em manter a clareza da alusão - tarefa que se faria necessária caso nos propuséssemos a traduzir também o poema de Púchkin. Não obstante, a citação não é privilégio unicamente do homenageado: há também referências diretas a Jukóvski, dispersas entre os versos 39 e 56, e, característica até emblemática do método de criação de Lérmontov, a composição em si surge como uma colcha de retalhos entre os gêneros da época, passando pela ode (sobretudo no início e

8 “Стихотворение, написанное на смерть Пушкина (1837 г.), является ярким образцом Аермонтовского ораторского стиля и декламационного стиха. ПереА нами страстная речь оратора: речевые периоды, сменяя Аруг Аруга, образуют целую скалу голосовых тембров - от скорбного Ао гневного, полного угрозы, а в промежутках межАу этими периодами явАяются патетические повторения, восклицания и вопросы, за которыми чувствуется эмоциональная жестикуляция” 
no fim do poema) e pela elegia (destacando-se os versos 35-45), e se estruturando em diversas métricas (MANÚILOV 1981, pp. 511-513).

Neste quesito, optou-se por uma correlação entre os diversos metros russos e alguns metros brasileiros (tetrâmetro - decassílabo, hexâmetro - tetradecassílabo, pentâmetro - dodecassílabo, trímetro - heptassílabo), ${ }^{9}$ mantendo-se estritamente a correlação entre eles. Tais correspondências entre os dois sistemas métricos são, evidentemente, arbitrárias. Mesmo se considerarmos, por exemplo, uma proximidade relativa no tamanho dos metros, não há nada que garanta uma perfeita correspondência entre um tetrâmetro iâmbico e uma redondilha maior, ou mesmo um octossílabo - verso que, a princípio, tem um número equivalente de sílabas, mas possui emprego e significado histórico em nada análogo ao do tetrâmetro iâmbico no sistema literário russo. Assim sendo, o único aspecto métrico considerado efetivamente objetivo foram as correlações rítmicas internas, ou seja, a combinação relativa entre metros de durações distintas articulados no poema. Aqui, seguiu-se escrupulosa e talvez excessivamente o esquema descrito, mas outras soluções, com diferentes metros e com variações em suas correlações, também poderiam preservar a estrutura, para nós essencial, do texto traduzido.

Ainda no tocante à versificação, é indispensável mencionar a importância que o andamento assumiu no nosso trabalho tradutório, uma vez que é ele, e não um número abstrato de sílabas, que empresta um ritmo ao poema. Enquanto os decassílabos foram compostos em sua grande maioria em andamento heroico (tônica na sexta sílaba), devido ao seu aspecto solene e à sua constante presença no Romantismo brasileiro, os outros versos receberam uma distribuição rítmica variável, ainda que sempre se atentando para a fluidez ${ }^{10}$ dos versos e evitando-se as construções sintáticas truncadas ou afetadas.

Respeitou-se, ademais, o máximo possível a pontuação do original, alterando-a somente quando o seu uso se explicasse unicamente pela gramática normativa russa, ou quando a sintaxe da tradução assim o exigisse: nos versos 35 e 36, por exemplo, foram empregados travessões ausentes no original, devido a razões sintáticas - caso não se isolasse o verso 36, poderia haver confusão entre o "cantor obscuro" e o "ser cego e invejoso", sendo que no original, tratando-se de uma prosopopeia (literalmente, "A presa de um ciúme surdo"), tal ambiguidade é

9 Salvo no caso da epígrafe, onde a correlação foi: tetrâmetro - eneassílabo, trímetro - heptassílabo, pentâmetro - decassílabo.

10 Atentou-se, nesse sentido, para a origem etimológica da palavra ritmo, ligada a rheo, 'fluir', entendida como 'forma do movimento' (CHANTRAINE 1977, p. 979). 
inexistente. A pontuação, cumpre enfatizar, é de extrema importância para a manutenção da "entonação oratória" de que nos fala Eikhenbaum (1924). O uso intenso de exclamações e de interrogações, articulado ao emprego da segunda pessoa do plural, empresta ao texto seu ar de discurso, efetivamente dirigido a uma plateia.

Buscamos também manter as assonâncias e aliterações que figurassem como significativas: no verso 50, por exemplo, recorreu-se à assonância da vogal 'i', e à aliteração do fricativo alveolar surdo (expresso pelas letras 's' e 'c') e de sons sibilantes (um deles, representado pela letra 't', o é ao menos na variante do português brasileiro falado na cidade de São Paulo, onde soa como / t $\lceil/$ diante da vogal 'i') para reproduzir os efeitos da aliteração das sibilantes no original: Com o cretino cochicho de trocistas imbecis [Kovarnym chopotom nasmechlivykh neviejd]. Consideramos este efeito sonoro como de extrema importância, uma vez que, estando associado semanticamente a "cochicho", "murmúrio", "boato", etc., reproduz no próprio significante o objeto significado. Por sua vez, as simples composições melódicas, eufônicas, do verso sofreram um processo de recomposição em português, sem necessariamente contar com os mesmos sons do original. Conforme nos lembra Meschonnic (2010, pp. 111-112), dada a diversidade dos arcabouços sonoros nos diversos idiomas, a manutenção de aspectos fonológicos idênticos na tradução entre duas línguas é impossível - fato que havia sido admitido até mesmo por Ezra Pound -, ou talvez exigisse uma tradução preocupada unicamente com esse aspecto do texto, implicando o sacrifício de outros elementos que julgamos tão ou mais importantes.

Por fim, recorreu-se, sempre que necessário, a compensações ${ }^{11}$ recriadoras nas passagens em que a perda de fatores importantes fosse inevitável. Como exemplo, podemos mencionar o verso 12, onde a inversão sintática do original (Sud'by sverchilsia prigovor - adjunto adnominal + verbo + núcleo do sujeito) foi convertida em uma estrutura bastante familiar para o português moderno, de modo a compensar eventuais recursos a inversões sintáticas inexistentes no original (como nos versos 17 e 18 da tradução, entre outros, em que o objeto direto antecede o sujeito e o verbo). Considerando que a organização sintática de Lérmontov tende a soar bastante natural para os padrões do russo moderno, o abuso de inversões seria absolutamente indesejável - arriscaria tornar pedante um autor que tem na

11 Segundo José Paulo Paes, a compensação é “a estratégia básica da tradução de poesia”, sendo que "nas possibilidades permutativas (ou compensatórias) das equações verbais, vale dizer, na possibilidade de produzir com meios diferentes efeitos análogos [...], é que a tradução de poesia encontra o fundamento da sua praticabilidade" (PAES 1990, pp 38, 39-40). 
simplicidade um de seus méritos e um de seus diferenciais históricos, uma vez que a modernização sintática foi uma das maiores contribuições que Púchkin legou aos seus sucessores.

A recriação também se fez presente nas ocasiões em que a reconstituição das ideias e da forma original não garantiu o número de sílabas ou o andamento necessário. Assim, a já citada opção por determinados metros propiciou diversas oportunidades para esse exercício, uma vez que, mesmo descontada a proverbial abundância silábica do português em relação a outras línguas (como o inglês, o francês e, em larga medida, o russo), a escolha de metros maiores do que os seus correlatos russos matematicamente diretos implicou diversos espaços para a atividade recriadora. Tal atividade foi norteada pelo tom oratório e sentimental do original, sempre com a preocupação de se evitar máximo a inclusão de simples rípios, privilegiando a adjetivação (como na linha 6 , em que os três adjetivos não possuem correspondência sintática com o original) e o uso de imagens hiperbólicas e condizentes com o vocabulário de Lérmontov (como na linha 19, onde o "cometa", palavra com 8 ocorrências em toda a obra do poeta, foi introduzido no lugar da "tocha" do original) (MANÚILOV 1981). Nessas situações, o exercício da tradução foi precisamente o trabalho a que nos propusemos: uma recriação (no sentido haroldiano) de uma poética (como a define Meschonnic) romântica (conforme os estudos históricos de Elias Saliba e Michel Löwy) (CAMPOS 2006; MESCHONNIC 2010; SALIBA 2003; LÖWY; SAYRE 1995).

Evidentemente, nem tudo que se perdeu no processo tradutório pôde ser devidamente compensado. O exemplo mais relevante é sem dúvida a posição das palavras "morre um Poeta" no verso 4, uma vez que, no original, é justamente delas a função de abertura do poema, o que lhes dá pela sua própria força semântica e pela posição inicial uma intensa carga dramática. Embora, de acordo com o esquema rímico, tal verso pudesse ter na tradução sua posição simplesmente trocada pelo verso 1 , ainda assim a oração citada não abriria o poema, de modo que se preferiu mantê-lo na linha 4, transformando os versos anteriores em uma espécie de introdução, inexistente no original, mas que, na suspensão provocada por suas orações subordinadas adverbiais, gera um efeito dramático compensatório.

\section{Conclusão}

A tradução e a análise de "A morte de um poeta" poderiam por si mesmas ser o objeto de toda uma pesquisa, tamanha é sua importância histórica, sua dramaticidade e sua força discursiva. Limitamo-nos aqui ao essencial: ao traduzir 
esta obra, tendo em mente o contexto histórico que a gerou e suas características principais, buscou-se a reprodução de seu tom em língua portuguesa - o que se manifesta sobretudo na escolha vocabular, no emprego de adjetivos, no relativo prosaísmo da linguagem e sobretudo na atmosfera sentimental que a perpassa. Desse modo, acreditamos ter conseguido, com razoável sucesso, elaborar um poema com as características que consideramos mais essenciais à obra original e ao seu autor, e que carrega, assim, a historicidade específica que faz dela uma obra digna de ser lida e traduzida quase duzentos anos depois de sua elaboração.

\section{Referências bibliográficas}

AUBERT, Francis. As (in)fidelidades da tradução. 2a ed. Campinas: Ed. da UNICAMP, 1994. CAMPOS, H. Metalinguagem e outras metas. $4^{a}$ ed. São Paulo: Perspectiva, 2006.

CANDIDO, A. Estudo analítico do poema. $4^{a}$ ed. São Paulo: Humanitas, 2004.

CHANTRAINE, P. (Org.). Dictionnaire Étymologique de la Langue Grecque, t. 4. Paris: Éditions Klincksieck, 1977.

EIKHENBAUM, B. Liermontov: Opyt istoriko-literaturnoi otsienki. Leningrado: Gosudarstvennyi Izd., 1924.

. "Literaturnyi byt" in O literatúrie. Moscou: Sov. Pisatiel', 1987.

JAKOBSON, R. Linguística e comunicação. Trad. Isidoro Blikstein e José Paulo Paes. São Paulo: Cultrix, 1969.

KOSELLECK, R. Futuro passado. Trad. Wilma P. Maas e Carlos A. Pereira. Rio de Janeiro: Contraponto: PUC-Rio, 2006.

LÉRMONTOV, M. I. Sobraniie sotchinenii v tchetyriekh tomakh. Moscou: Khudojestvennaia Literatura, 1964.

. O herói de nosso tempo. Trad. Paulo Bezerra. São Paulo: Martins Fontes, 1999.

LÖWY, M.; SAYRE, R. Revolta e melancolia. Petrópolis: Vozes, 1995.

MANÚILOV, V. A. (Org.). Liérmontovskaia Entsiklopiédiia. Moscou: Soviétskaia Entsiklopiédioa, 1981.

MESCHONNIC, H. Poética do traduzir. Trad. Jerusa P. Ferreira e Suely Fenerich. São Paulo: Perspectiva, 2010.

PAES, J. P. Tradução: a ponte necessária. São Paulo: Ática, 1990.

POUND, E. $A B C$ da literatura. Trad. Augusto de Campos e José Paulo Paes. São Paulo: Cultrix, 1970.

RÓNAI, P. A tradução vivida. Rio de Janeiro: Nova Fronteira, 1981. 
56 Pedro Augusto Pinto. A morte de um Poeta. Tradução poética para o português da estreia...

. Escola de tradutores. $2^{\mathrm{a}}$ ed. Rio de Janeiro: Livraria São José, 1956.

SALIBA, E. As utopias românticas. 2a ed. São Paulo: Estação Liberdade, 2003.

SCHNAIDERMAN, B. Traducão, ato desmedido. São Paulo: Perspectiva, 2011.

SIÉRMAN, I. Mikehail Liermontov: jiæn' v literaturie 1836-1841. Moscou: RGGU, 2003.

STAROBINSKI, J. L'Encre de la mélancolie. Villeneuve-D'Ascq: Éditions du Seuil, 2012. 